\title{
Clinical simulation in teaching Pediatric Nursing: students' perception
}

\author{
Simulação clínica no ensino de Enfermagem pediátrica: percepção de estudantes \\ Simulación clínica en educación pediátrica de enfermería: percepción estudiantil
}

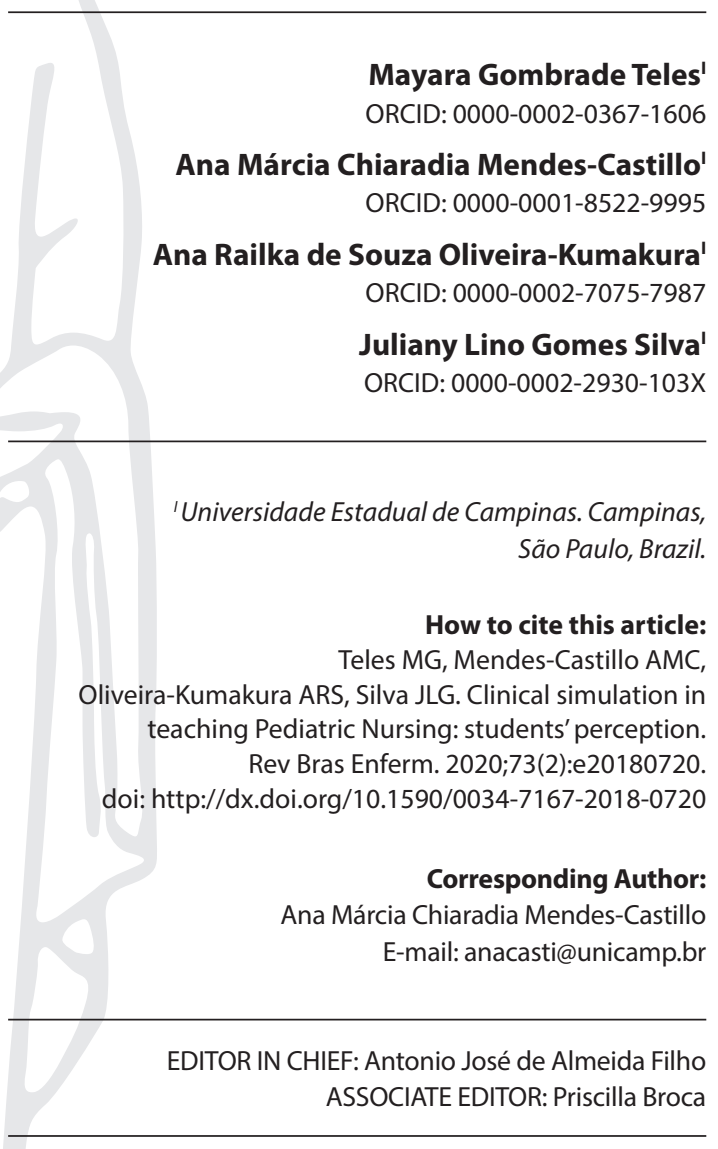

Submission: 09-19-2018

Approval: 03-23-2019

\begin{abstract}
Objectives: to comprehend the perception of undergraduate nursing students about learning to care for the child and family through clinical simulation. Methods: this is a qualitative research conducted with ten nursing students through semi-structured interviews. Data were analyzed through content analysis. Results: data were organized into two categories: "learning a new way to learn," in which students describe their experiences during the simulation, and "learning a new way to care," in which they reflect on learning through simulation. Final considerations: we believe that clinical simulation practice in teaching should be encouraged because of the benefits it can offer to the students, faculty, patients and their families. However, we recommend further studies to validate scenarios of child and family healthcare.

Descriptors: Nursing Students; Pediatric Nursing; Simulation; Qualitative Research; Nursing Education.
\end{abstract}

\section{RESUMO}

Objetivos: conhecer as percepções dos estudantes de graduação em Enfermagem acerca de aprender o cuidado da criança e da família por meio da simulação clínica. Métodos: tratase de uma pesquisa qualitativa realizada com dez estudantes de Enfermagem por meio de entrevistas semiestruturadas. Os dados foram analisados por meio da análise de conteúdo. Resultados: os dados foram organizados em duas categorias: "aprendendo uma nova forma de aprender", em que os estudantes descrevem suas experiências ao vivenciar a simulação, e "aprendendo uma nova forma de cuidar", na qual eles refletem sobre os ganhos da simulação no aprendizado. Considerações finais: consideramos que a prática da simulação clínica no ensino deve ser encorajada em razão dos benefícios que podem trazer a alunos, docentes e aos pacientes e suas famílias. Entretanto, recomendamos a realização de novos estudos com o intuito de validar cenários na atenção à criança e sua família.

Descritores: Estudantes de Enfermagem; Enfermagem Pediátrica; Simulação; Pesquisa Qualitativa; Educação em Enfermagem.

\section{RESUMEN}

Objetivos: conocer las percepciones de los estudiantes de grado en Enfermería acerca del aprendizaje del cuidado del niño y su familia por medio de la simulación clínica. Métodos: se trata de una investigación cualitativa en la cual participaron diez estudiantes de Enfermería por medio de entrevistas semiestructuradas. Se analizaron los datos mediante el análisis de contenido. Resultados: se ordenaron los datos en dos categorías: "aprendiendo una nueva forma de aprender", en que los estudiantes describen sus experiencias al experimentar la simulación, y "aprendiendo una nueva forma de cuidar", en que reflexionan sobre la utilidad de la simulación en el aprendizaje. Consideraciones finales: constatamos que la práctica de la simulación clínica en la enseñanza debe ser alentada debido a la utilidad que puede aportar a los alumnos, a los docentes y a los pacientes y sus familias. Sin embargo, recomendamos la realización de nuevos estudios con el fin de validar contextos en la atención al niño y su familia.

Descriptores: Estudiantes de Enfermería; Enfermería Pediátrica; Simulación; Investigación Cualitativa; Educación en Enfermería. 


\section{INTRODUCTION}

On November 7, 2001, the Ministry of Education launched the National Curriculum Standards for the Nursing Undergraduate Course (DNCENF), aiming to standardize, nationwide, the Nursing education. In addition to the profile and skills expected from the student, the new standards encouraged the update of the pedagogic project of the schools and the use of new strategies for Nursing education ${ }^{(1)}$.

In this document, the students are presented as the subjects of their own learning experience, while the professor is the facilitator of the teaching-learning process. This redefinition often poses challenges for both student and professor regarding the implementation of the knowledge in the integral care for specific populations, such as children and adolescents. With these changes, the need to rethink the traditional model that predominated in the Brazilian undergraduate Nursing courses became evident ${ }^{(1-2)}$, enabling new teaching methodologies.

The use of active methodologies has been widely discussed, with emphasis on the clinical simulation, which has a problem-based learning approach (PBL), aiming to cause a rupture in the traditional Nursing education by promoting the student's autonomy ${ }^{(3-4)}$.

Clinical simulation in healthcare aims to reproduce techniques and care measures in a controlled and protected environment to expand the theoretical-practical knowledge of professionals and students, offering minimal risks for participants ${ }^{(5-9)}$.

In Brazil, clinical simulation for teaching Nursing skills is relatively recent, but has been gaining more space in the universities due to its diversity of applications ${ }^{(10-12)}$. Evidence shows it is an important and innovative strategy that aims to consolidate and facilitate the students' teaching-learning process ${ }^{(13)}$, with increasingly explicit benefits, not only in the technical area, but also in the relational one, for allowing the development of technical and non-technical skills (communication, clinical reasoning, decision-making, among others).

The simulation can be divided into three phases: pre-briefing and briefing, scenario (or simulation) and debriefing, phase in which participants share feelings and possible improvements for situations that took place during the scenario(14).

The objective of this process of repetition in a controlled and protected environment is to ensure patient safety, in addition to developing the student's confidence to deal with the most vulnerable populations ${ }^{(2,15)}$. It is noteworthy that beginner mistakes become even more damaging when working with older adults and children, the latter being the focus of this study ${ }^{(12,16-17)}$.

For students, the advantage of experiencing the simulation as undergraduates is the ability to reproduce the procedures over and over again, without putting the patient at risk, which makes them feel safer during clinical practice ${ }^{(9,18-19)}$. Another advantage reported is to experience simulated practices similar to theoretical teaching, not always seen in the clinical context, which expands the theoretical-practical knowledge, without exposure to risks ${ }^{(9,18-19)}$.

This finding strengthens the existing relationship between the incentive to the simulated practice and patient safety. When dealing with vulnerable subjects, such as children and their families, we can assume these feelings would persist and that patient safety would increase, as well as the confidence of future professionals.

In the healthcare of children, the key skills for an effective work go far beyond the techniques, whereas it is necessary to develop the relationship between child and family. The approach we adopt is the child and family centered care (FCC), which values communication, information sharing and collaborative relationship ${ }^{(20)}$.

The teaching of the principles of FCC remains a challenge because its merely theoretical content, when dissociated from practice, can lead to forgetfulness or misunderstanding. Given this context, the simulation is important, as it is well known as an effective and fundamental method to achieve specific goals in the clinical environment.

Although the study on simulation is growing in Brazil, especially in the last five years, when it comes to new methodologies in children and family healthcare, it is still limited, thus requiring new investigations ${ }^{(5-6)}$. Therefore, studies on the effects of this educational strategy are still scarce in our culture, especially from the perspective of students ${ }^{(6,16-17)}$.

\section{OBJECTIVE}

To comprehend the perception of undergraduate nursing students about learning to care for the child and family through clinical simulation.

\section{METHOD}

\section{Ethical aspects}

All ethical conduct advocated by Resolution 466/2012(21), which addresses research involving human beings, was strictly adopted in this study at all phases. The research project was approved by the Research Ethics Committee of the University of Campinas.

\section{Study approach}

This is a qualitative descriptive research project that aimed to understand a phenomenon - to learn about child and family healthcare through clinical simulation - according to the subject's point of view, namely, undergraduate Nursing students ${ }^{(22)}$.

\section{Study location}

Data were collected in the Nursing school of a public university in a city of the state of São Paulo, which holds anually 40 entering students and has a 4,050-hour pedagogic program.

\section{Data sources}

From September 2017 to May 2018, students who had attended the discipline"EN665 - Nursing care for children and adolescents II" in the second term of 2016 were invited to participate in the study. This discipline aims to provide resources so the student can develop the Nursing care for children and adolescents with diseases of medium and high complexity, based on the integral care, having a child- and family-centered care as a principle.

We considered as inclusion criteria that students had attended the discipline and went through the clinical simulation activities. The exclusion criteria were not being regularly enrolled in the Nursing undergraduate course at the time of data collection or being out on a medical leave. 
We developed five scenarios to address different clinical situations in Pediatric Nursing. The National League for Nursing/Jeffries Simulation Framework (NLN/JSF) was an essential guidance basis for the creation, implementation and evaluation of the scenarios. The model consists of five dimensions: teaching practices, professor, students, design and characteristics of the simulation and outcomes ${ }^{(23)}$.

During simulations, students had the opportunity to perform more than one role, alternating between observers, family members, Nursing students, nurses, and - few of them - pediatric patients. The goals of the scenarios were related to the application of the principles of FCC (communication, empathy, negotiation with the family ${ }^{(20)}$ ) in illness and pediatric hospitalization.

High-fidelity simulations were carried out with groups of five and six students, two of whom entered the scenario playing the role of Nursing students, another as the family member, while the others were observers. Each scenario lasted, on average, 20 minutes. Before the execution, the students had about 60 minutes of previous reading to study the theme of the scenario. Debriefing was guided by five main questions evaluating the emotional, descriptive, evaluative, analytical and conclusive phases, with each session lasting approximately 60 minutes $^{(24)}$.

\section{Data collection and organization}

Participants were personally invited to the study by a senior student, who was writing her final course paper on this topic.

Data were collected through semi-structured interviews, that started with a guiding question: "Tell me how was your experience with clinical simulation in the Pediatric Nursing course." The interviews were also conducted by the senior student, upon previous training. A convenience sampling was used to select the participants, and none of them refused to participate.

Before the interview, we collected sociodemographic data for characterization. The interviews were recorded on digital audio and performed in a single contact, which lasted, on average, 25 minutes. Soon after, they were fully transcribed. Saturation was used as a criterion to define the moment to interrupt data collection ${ }^{(19)}$.

\section{Data analysis}

The analysis was made through the content analysis technique and was derived from the data, that is, the codes and categories were not previously determined ${ }^{(19)}$. In content analysis, the first step is to encode the data, that is, to identify words, phrases, and situations that appear consistently as to recognize references for later analysis. After this phase, the researcher becomes familiar with the data and begins to organize the information, which is made by exhaustive reading of the data, highlighting the persistent points or those that mostly stand out.

After coding, the researcher goes through the data again, separating all points highlighted and regrouping them in distinct categories. After reading each category again, subcategories can be created, one of which is briefly described and questioned regarding its homogeneity. In the last phase, integration, the data are reanalyzed to identify possibly existing relations between categories, themes that emerged from this research project and the conclusions that can be drawn from the study.

\section{RESULTS}

Ten out of the sixteen students who have experienced clinical simulation were interviewed. At the time of the interview, all students were in the fifth year of the course, being one man and nine women. Ages ranged between 21 and 33 years, and only one of the participants had children. About religious affiliation, there were three Catholic people, three Protestant/Christians, one Spiritist, and three of them reported not following any religion.

Through the data analysis, we observed that the perception students have about the clinical simulation in the learning process of the child and family healthcare can be divided into two categories: "learning a new way to learn" and "learning a new way to care."

\section{Learning a new way to learn}

In this first category, we describe how the introduction of clinical simulation in the discipline of pediatric Nursing challenged students. They have experienced the activity as something new in their qualification because their previous contact with clinical simulation was specific, limited to one or two experiences in other courses. Therefore, as they described their experiences with child and family healthcare, we realized that they were involved, first of all, in a process of learning to learn.

Because it is a new experience, students began the simulation feeling apprehensive and distrustful, even though they were also curious. They did not know how it would work, if they would feel realism in the scene, or if they would be able to perform while being observed. In addition, they had doubts about whether the simulations would have an evaluative character on the part of the professor in charge of the activity.

I remember when the clinical practice areas were divided, the simulation was considered to be one area, and as we did not have much contact, we were all a little suspicious. (R2)

As the scenarios developed and they had the opportunity to experience different roles, to join the debriefing, to listen and to contribute to discussions, the feelings of mistrust were replaced by familiarity and confidence in participating in the simulation.

And then the last two simulations were also very easy because we were more relaxed and understood the role of the professor and of the simulation. (R5)

The fear that the experience was not going to be believable was also resignified as students observed, alternated roles, and got involved in the experience. Students experienced distinct feelings in the scenarios, they even cried when giving bad news and reflected upon the experience, mentioning that they were really involved in the scene, and it was really realistic.

In a very serious situation I got really emotional! (R4)

I think the secret is to dive right in, because you forget about the world, as if the scene were totally real, and you feel the same things that you would probably feel in practice. (R7) 
From the students' perspective, the need for a new learning approach also comes from the fact they had to understand that playing different roles in a scenario can contribute to their qualification. One of the gains of playing a family member or patient was being in these people's shoes and changing the way of dealing with them, since after this experience, the students reported having a more sensitive and empathetic behavior.

I think it's very important to go through the three phases, being a family member, being the nurse and being the observer in order to have these three perspectives and feelings, because sometimes we feel helpless, like a failure, so I think it's cool to go through these three experiences in the simulation! (R7)

Thus, the students attributed meaning and relevance to the opportunity of playing different roles and saw that as a possibility of transforming the learning process. Even those who were not on the scene, that is, those watching their colleagues, revealed they learned a lot about the theme of the scenario, since after the performance there was a debriefing session about everything that had been performed.

In this sense, they believe that the benefit of learning also extends to those who did not feel at ease on the scenario for being shy, since they could enjoy this discussion as any other student. So, debriefing was considered a key moment by and for all students, even by those who did not want to perform.

I think people who are shy can enjoy more the discussion because they are outside the scene and can observe what is going wrong and what needs improvement, so it is an opportunity, even if they don't perform, of seeing what could change. (R6)

Students reported that different personalities can influence the performance in the scenarios. Some may be more reserved, while others are not bothered. However, although different personalities were in constant interaction in the simulated scenario, students believe that it does not influence or take the seriousness away of the scene, nor disturb the learning process. By learning a new learning approach, they consider that such differences do not interfere in the seriousness or in the realism of the activity.

What I also liked was that even though it was a simulation it was serious and it didn't become embarrassing. (R8)

As well as the debriefing session, the previous reading moment was reported as being a significant benefit for knowledge, being seen as an aid for better resourcefulness in the upcoming scenario and making the whole process less stressful. Through prior reading, students were in contact with the theme of the scenario, so they knew what it was and could refer to the literature, which was available for about 45 minutes. All this reinforces the nonevaluative character with which the simulation was employed, leaving them increasingly comfortable in participating.

The objective was to make me learn, I didn't feel as if that moment was being evaluated, if I couldn't do the right thing, you know? (R5)

The more students participated in scenes, the more they learned about this new learning approach and raised confidence in the methodology. With that, the initial feeling of apprehension was replaced by satisfaction, recognition of the simulation as something good and important for their education and that it should be kept in the discipline and included in other opportunities during the course.

After perceiving the simulation as a tool that can help them create their professional identity, students reflected upon their value to the detriment of their own practical activity. For them, the practice often provides the opportunity to replicate what is done by the professor, while the simulation allows them to be the protagonists in the scene and to have decision-making autonomy.

A replica of other nurses, other professionals, we are always the same. The simulation challenges us to not be a replica, but ourselves, creating our identity as nurses. (R1)

In the practice, the professor has the responsibility to promote the safety of students and patient, in the simulation that safety and confidence are assured to all, since this is a fictional situation in which the harms are minimized. This helps the simulation become a more innovative strategy of both techniques and other skills, without putting anybody at risk during the process.

In the hospital we are dealing with real lives, we can fail or succeed, which is difficult because the professor has to watch everyone and everything we're doing. With the simulation we keep doing all that, working together, but I think we get more confident, as well as the professor. (R2)

\section{Learning a new way to care}

Once immersed in a new learning process, students also experienced a different healthcare approach. The focus of this very Pediatric Nursing course aimed to consider the child, the adolescent and the family as the unit of the care. Thus, the scenarios were also planned for that purpose, i.e., they aimed at a Nursing care that goes beyond the technical care, bypassing the skills needed for the nurse to ensure the family-centered care in an integrated manner. In this category, we understand how students learn a new way to care for children and their family through clinical simulation.

The participants reported difficulties or low affinity in dealing with children and that, after the simulation, this situation improved. Thus, many could feel more comfortable in dealing with a sick child and his/her family.

It is very delicate for me to deal with a child and his/her parents because the child is your patient, but you also have to give support for the parents if they need it, count on their help, that makes all the difference. (R3)

The experiences in different scenarios made the students reflect upon how, in practice, the care extended to the family unit is offered. The concepts transmitted in the classroom were resumed in the scenarios and during the debriefing session, making the association between theory and practice clearer.

If we have a sick child, we have to take care of him/her, but we also have to take care of the family that is going through this, so I think the simulation helped me on that too, because we only see this in theory. Oh! It's a care unit, but it's different in practice, and the simulation was able to gather those two things. (R2) 
Many students reported that their experiences in the simulation could really happen in practice, and often did, but they saw themselves more secure and confident to make decisions and deal with the situation, since it was no longer something new.

I think performing the role of the child is the best part of the simulation, as it allows us to consider the context of being hospitalized or undergoing some procedures, if we had not had those previous experiences maybe it'd be more shocking in practice, without prior experience. (R10)

But there was a simulation that was very similar to one we saw in practice, or a similar case that made us think about what we had seen in the simulation, which helped clarify some points on how to act in practice and the notion I had of Pediatrics. (R3)

In addition to these abilities, the development of technical skills focused on Pediatrics and familiarity with new equipment - such as burette, oxygen tent and pediatric oximeter - was enabled by the simulation, before and after the scenarios. Thus, the students practiced more before going to the hospital and could resolve their doubts regarding the equipment.

I wouldn't like if someone who does not feel secure or who didn't attend the scenario handled my kid, one of the simulations addressed the issue of using a burette and it was very good for me because I understood its use and how the technique is applied. (R8)

In addition to elucidating the use of equipment or techniques, a great gain was to see beyond the procedure, that is, the person receiving the care. Since many students were used to the techniques and theories, they could focus more on the relational aspect and see the needs - not just the medicine, but the whole context of health - to promote an integral care.

I think the main thing is the way we deal with these people, looking at the whole context, we are too focused on the procedure but then we get more attentive because after the scene and the discussion, we see the criticism or the success, which helps us understand if we're doing it right or wrong. (R4)

Thus, we observed that the simulation did not change only the learning approach of students, but also their care, by generating a reflection about the way they employ their technical and non-technical skills and bring more safety, promoting thus a new look at the child and his/her family, as a healthcare network.

It made a huge difference, our focus is not only the child but the whole family, father, grandmother, uncle, aunt, whoever is there. (R3)

We realize what is missing, what is not missing, what you need, if you need to be more dynamic, critical, more sensitive, or tougher. (R4)

\section{DISCUSSION}

Our study analyzed the perspectives of Nursing students who have experienced the simulation as a teaching strategy for child and family care, and it emerged from two categories: "learning a new way to learn" and "learning a new way to care." In this context, the professor, who in most cases develops the educational practice, needs the best evidence to use the clinical simulation and ensure these feelings are developed. Examples on how to ensure the success of the educational activity for all involved are presented by the International Nursing Association for Clinical Simulation and Learning (INACSL). According to these recommendations, knowledge in simulation is essential for anyone who prepares the activities, in addition to following structural criteria to develop them (simulation design, outcomes and objectives, facilitators, debriefing, evaluation of participant, professional integrity and glossary for the simulation) ${ }^{(14)}$.

Given this context, Nursing educators need to understand and recognize the learning styles and characteristics of their students. A survey conducted with students of the third year of Nursing, similar to that of our sample, showed that high-fidelity simulation is valued by them, regardless of their learning styles, as long as their design aligns to what is expected from the professional practice ${ }^{(25)}$.

The feeling of insecurity about the simulation, mainly because it is one of the initial contacts with this technique, was verified in the first reports of students. Authors highlight that the students familiarity with the scenarios contributes to lower anxiety and to make them more experienced to deal with the teaching process ${ }^{(13)}$ and to gain knowledge ${ }^{(26)}$. The professor must consider those feelings when the simulation becomes a learning process ${ }^{(27)}$, since these feelings change over time.

This can be facilitated by the construction of high-fidelity scenarios, even if not using high-tech simulators, but at least with a high degree of realism by environmental and psychological fidelity. The fidelity of equipment proposed as a challenge did not seem to concern most students, although studies claim that high-fidelity simulators/ technology are more appreciated by the students due to the possibility of interacting with the scenario and the immediate feedback for the responses submitted ${ }^{(26,28)}$. For promoting the development of technical, cognitive and behavioral skills and improving clinical trial(29), we believe that the financial and budgetary difficulties of the educational institution must be overcome for the success of the activity. This can be done with careful planning of scenarios, in order to adapt it to local opportunities, increase it and ensure its realism.

The students reported they felt accomplished and important for playing different roles during the scenarios, including family members, patients and students. The literature shows that the use of the roleplaying strategy helps the learner develop clinical skills and effective communication for allowing the learner to play different roles ${ }^{(29)}$.

In addition to what has already been described, to participate more actively in the scenarios and work in small groups were singled out as significant aspects for the learning process. However, participants who considered themselves shy mentioned that watching their colleagues in attendance and participating in the debriefing session was also important to their learning. Such report corroborates a study on the perception of the students who learned by observing ${ }^{(25,30-31)}$ and stresses the importance to involve the students in the simulation through the recognition of learning styles and characteristics.

Many students reported that they were more comfortable and prepared for the actual practice after experiencing the simulations. This may have occurred because they knew there would be no clinical consequences for real patients if they made a mistake ${ }^{(26,28)}$ and because of the focus given to the emotional content and to the performance in the simulated clinical trials, which makes learning more dynamic and different ${ }^{(32)}$. 
The learning mentioned by the students was also a result of the way the professor acted during the process. The professor must support the students, create a friendly environment for learning and help develop their identity as nurses and not only conduct a moment for evaluation or value judgement ${ }^{(32)}$. Thus, the way the professor handles the simulation interferes with the learning process ${ }^{(28)}$. The use of clinical simulation as a teaching or evaluation method is noteworthy, which may be educational or summative, depending on the scenario design ${ }^{(33)}$.

In the category "learning a new healthcare approach,"it is important to indicate the stress of Nursing students before clinical trials with children. Such a feeling may be related to the vulnerability of the population and the other challenges that come with a pediatric approach, such as the patient him/herself, the impossibility of verbal communication in some contexts, fear of the health environment and anxiety by the presence of family members ${ }^{(28)}$.

Many students reported their difficulties in dealing with children or their low affinity with this population and the belief that this was a barrier to clinical care. However, after the simulation, they felt safer, as evidenced in other research, which associated this feeling of security to act in the practice, communicate and interact with the child after previous contact in simulated environment ${ }^{(26)}$.

Studies show that simulations make students more self-reliant to confront difficult situations, and the self-confidence reduces the anxiety and increases comfort ${ }^{(34)}$. A simulated environment with potentially valuable learning opportunities is where the practice, rehearsal, and improvement of specific Nursing skills begin ${ }^{(32)}$.

Given this context, communication is key to FCC, which was emphasized in the activity and in the reports. After the simulation, we observed that students were quite compelled to search for new techniques to communicate effectively with the families during and after the scenarios, ensuring other principles of FCC, such as information sharing and collaborative relationship ${ }^{(20)}$. Studies have defended the simulation as a method that develops behavioral skills, such as communication and empathy ${ }^{(29)}$, which require experiential and reflective learning strategies ${ }^{(26-27)}$.

Besides proper communication and relational skills, we observed that the learning of technical skills was meaningful for the participants. This is one of the benefits of the simulation presented in the literature in which there is the possibility of training procedures and contact with technologies in a safe environment, numerous times, without putting colleagues or patients at risk ${ }^{(9)}$.

As students get involved with the environment and the scenarios, they begin to react, to behave and feel like nurses, although it is a simulation-based learning environment. This differs from the traditional teaching model of Nursing in which students learned how to perform the technique in a classroom or laboratory of skills and improved this practice later in a healthcare environment ${ }^{(32)}$. Therefore, simulation allows the change from a vertical to horizontal learning model, which stimulates students questioning, participation and reflection.

Thus, the possibility of replicating the reality of scenes and conditions that would normally be seen in a nursing facility generates improvement and autonomy, not only to prepare the student for the practical environment, but also for a reflection on the type of professional identity he/she will assume ${ }^{(9,27-28,32)}$.

We believe that, for the Nursing student, learning FCC through realistic scenarios in a safe environment where it is possible to observe and practice different healthcare approaches is more effective. The literature shows that the horizontal learning enabled by the simulation makes the students consider the context of the care (background), carry out practical activities (performance), develop clinical reasoning (knowledge), interpret the Nursing information (interpretation), and develop their identity as nurses (qualification) ${ }^{(32)}$.

\section{Study limitations}

We considered as a limitation of the study the impossibility of participation of all the students who were involved in the clinical simulation scenarios.

\section{Contributions to the field of Nursing}

The objective of this study of inserting new methodologies in Nursing education contributed to the development of clinical reasoning of students in Pediatrics, favoring the child- and familycentered care. This teaching approach can extend for professionals in the clinical practice, thus promoting a safer nursing care and focusing on the development of technical and behavioral skills.

\section{FINAL CONSIDERATIONS}

The experiences of students regarding the simulation in the child and family care context show that they are aware of the need for a new approach, one that breaks with traditional teaching models and assumes a more active posture to overcome personal obstacles and immerse in a relational, solid and practical learning atmosphere. In addition, we saw that after entering in the simulation, the participants learn a new way to care for the child and its family, breaking the barriers they had in dealing with children, developing communication and negotiation skills and specific techniques and procedures.

Considering our results, we believe the practice of clinical simulation in undergraduate courses must be encouraged due to the potential benefits it can bring to students, professors, patients and their families. We recommend new studies be carried out with the aim to discuss and validate scenarios on child and family care, as well as to measure the impact of these teaching strategies in the qualification of nurses in our context.

\section{REFERENCES}

1. Brasil. Resolução CNE/CES no 3 de 7 de novembro de 2001. Institui Diretrizes Curriculares Nacionais do Curso de Graduação em Enfermagem. 2001 [cited 2018 Mar 12]. Available from: http://www.cofen.gov.br/wp-content/uploads/2012/03/resolucao_CNE_ CES_3_2001Diretrizes_Nacionais_Curso_Graduacao_Enfermagem.pdf. 
2. Martins JCA, Mazzo A, Baptista RCN, Coutinho VRD, Godoy SD, Mendes IA, Trevizan MA. The simulated clinical experience in nursing education: a historical review. Acta Paul Enferm. 2012; 25(4):619-25. doi: 10.1590/S0103-21002012000400022

3. Mitre SM, Siqueira-Batista R, Girardi-de-Mendonça JM, Morais-Pinto NM, Meirelles CAB, Pinto-Porto C, Moreira T, Hoffmann LMA. Metodologias ativas de ensino-aprendizagem na formação profissional em saúde: debates atuais. Ciênc Saúde Coletiva. 2008;13(2):2133-44. doi: 10.1590/S1413-81232008000900018

4. Sobral FR, Campos CJG. The use of active methodology in nursing care and teaching in national productions: an integrative review. Rev EsC Enferm USP. 2012;46(1):208-18. doi: 10.1590/S0080-62342012000100028.

5. Oliveira SN, Prado ML, Kempfer SS. Use of simulations in nursing education: an integrative review. Rev Min Enferm. 2014;18(2):487-95. doi: $10.5935 / 1415-2762.20140036$

6. Santos MC, Leite MCL. A avaliação das aprendizagens na prática da simulação em Enfermagem como feedback de ensino. Rev Gaúcha Enferm. 2010;31(3):552-6. doi: 10.1590/S1983-14472010000300020

7. Creswell JW. Qualitative inquiry and research design: choosing among five traditions. 3a ed. Thousand Oaks: Sage; 1998.

8. Santos MC, Leite MCL, Heck RM. Recontextualização da simulação clínica em Enfermagem baseada em Basil Bernstein: semiologia da prática pedagógica. Rev Gaúcha Enferm. 2010;31(4):746-52. doi: 10.1590/S1983-14472010000400019

9. Costa RRO, Medeiros SM, Martins JCA, Menezes RMP, Araújo MS. O uso da simulação no contexto da educação e formação em saúde e Enfermagem: uma reflexão acadêmica. Rev Espaço Saúde. 2015;16(1):59-65. doi: 10.22421/1517-7130.2015v16n1p59

10. Teixeira INDO, Felix JVC. Simulação como estratégia de ensino em Enfermagem: revisão de literatura. Interface-comunicação, saúde, educação. 2011;15(39):1173-84. doi:10.1590/S1414-32832011005000032

11. Ministério da Saúde (BR). Documento de referência para o Programa Nacional de Segurança do Paciente. Brasília: Ministério da Saúde; 2014 [cited 2018 Mar 12]. Available from: http://bvsms.saude.gov.br/bvs/publicacoes/documento_referencia_programa_nacional_seguranca.pdf

12. Fonseca LMM, Góes FSN, Ferecini GM, Leite AM, Melo DF, Scochi CGS. Inovação tecnológica no ensino da semiotécnica e semiologia em Enfermagem neonatal: do desenvolvimento à utilização de um software educacional. Texto Contexto Enferm. 2009;18(3):549-58. doi: $10.1590 /$ S0104-07072009000300019

13. Kardong-Edgren SE, Starkweather AR. The Integration of Simulation into a Clinical Foundations of Nursing Course: student and faculty perspectives. Int J Nurs Educ Scholarsh. 2008;5(1):1-16. doi: 10.2202/1548-923X.1603

14. INACSL Standards Committee. INACSL Standards of Best Practice: SimulationSM simulation design. Clinical Simulation in Nursing. 2016;12(S): S48-50. doi: 10.1016/j.ecns.2016.09.005

15. Bishop S, Stewart P. Simulation: a day in the Life of a pediatric nurse. J Nurs Educ. 2014;53(3):174-6. doi: 10.3928/01484834-20140219-01

16. Parker RA, McNeill JA, Pelayo LW, Goei KA, Howard J, Gunter MD. Pediatric clinical simulation: a pilot project. J Nurs Educ. 2011;50(2),105111. doi: 10.3928/01484834-20101230-05

17. Bonamigo EL, Destefani AS. A dramatização como estratégia de ensino da comunicação de más notícias ao paciente durante a graduação médica. Revista Bioética. 2010 [cited 2018 Jul 20];18(3):725-42. Available from: http://revistabioetica.cfm.org.br/index.php/revista_bioetica/ article/viewFile/596/602.

18. Martins JCA, Mazzo A, Mendes IAC, Rodrigues MA. A Simulação no ensino de Enfermagem. Ribeirão Preto: Sobracen; 2014.

19. Mayan MJ. An introduction to qualitative methods: a training module for students and professionals. Alberta, Canada: International Institute for Qualitative Methodology; 2001.

20. Wright LM, Leahey M. Enfermeiras e famílias: guia para avaliação e intervenção na família. 5a ed. São Paulo: Roca; 2015.

21. Ministério da Saúde (BR). Resolução CNS/MS n 466, de 12 de dezembro de 2012. Diário Oficial da União [Internet]. 2013 Jun 13 [cited 2018 Oct 20]. Available from: http://conselho.saude.gov.br/resolucoes/2012/Reso466.pdf

22. Jeffries PR, Rogers KJ. Simulation in nursing education: From conceptualization to evaluation. $2^{\mathrm{a}}$ ed. New York: National League for Nursing; 2012. p. 25-41.

23. Gibbs G. Learning by Doing: a guide to teaching and learning methods. Further Education Unit.: Oxford Polytechnic: Oxford; 1988.

24. Tutticci N, Coyer F, Lewis PA, Ryan M. High-fidelity simulation: descriptive analysis of student learning styles. Clinical Simulation in Nursing. 2016;12(11): 511-21. doi: 10.1016/j.ecns.2016.07.008

25. Gamble AS. Simulation in undergraduate paediatric nursing curriculum: Evaluation of a complex 'ward for a day'education program. Nurse Educ Pract. 2017;23:40-7. doi: 10.1016/j.nepr.2017.02.001

26. Shin $\mathrm{H}, \mathrm{Ma} \mathrm{H}$, Park J, Ji ES, Kim DH. The effect of simulation courseware on critical thinking in undergraduate nursing students: Multi-site pre-post study. Nurse Educ Today. 2015;35(4):537-42. doi: 10.1016/j.nedt.2014.12.004

27. Darcy Mahoney AE, Hancock LE, lorianni-Cimbak A, Curley MA. Using high-fidelity simulation to bridge clinical and classroom learning in undergraduate pediatric nursing. Nurse Educ Today. 2013;33(6):648-54. doi: 10.1016/j.nedt.2012.01.005

28. Bauchat JR, Seropian M, Jeffries PR. Communication and empathy in the patient-centered care model-Why simulation-based training is not optional. Clin Simul Nurs. 2016;12:356-9. doi: 10.1016/j.ecns.2016.04.003

29. Rabelo L, Garcia VL. Role-Play para o desenvolvimento de habilidades de comunicação e relacionais. Rev Bras Educ Méd. 2015;39(4):586-96. 
doi: 10.1590/1981-52712015v39n4e01052014

30. Bowling AM, Eismann M. An innovative and successful simulation day. Nurs Educ Perspectives. 2017;38(2):96-97. doi: 10.1097/01. NEP.0000000000000107

31. Berragan L. Conceptualising learning through simulation: An expansive approach for professional and personal learning. Nurse Educ in Pract. 2013;13(4): 250-5. doi: 10.1016/j.nepr.2013.01.004

32. INACSL Standards Committee. INACSL Standards of best practice: SimulationSM Participant evaluation. Clin Simul Nurs. 2016;12(S):S26-9. doi: 10.1016/j.ecns.2016.09.009

33. Khadivzadeh T, Erfanian F. The Effects of Simulated patients and simulated gynecologic models on student anxiety in providing IUD services. Simul Healthcare. 2012;7(5):282-7. doi: 10.1097/SIH.0b013e31826064b7

34. Lewis M, Bell J, Asghar A. Use of simulated patients in development of physiotherapy students' interpersonal skills. IJTR. 2008;15(5):221-9. doi: 10.12968/ijtr.2008.15.5.29234 